\title{
PENGARUH LEADER MEMBER EXCHANGE (LMX) \\ DAN KEPUASAN KERJA TERHADAP ORGANIZATIONAL CITIZENSHIP BEHAVIOR (OCB) GURU \\ SD SWASTA DI KECAMATAN MENTENG JAKARTA PUSAT
}

\author{
Budijanto 1
}

\begin{abstract}
The objective of this research was to understand the effect of leader member exchange (LMX) and job satisfaction on organizational citizenship behavior (OCB). It was a quantitative research. The research used is a survey method with a correlation approach. In this study serve as a sample of 81 teachers were selected based on random techniques (simple random sampling). Data were obtained by spreading questioner. This study was conducted in private elementary schools at the district Menteng, Central Jakarta. The result of this study are: (1) there is a positive direct influence of leader member exchange on $O C B,(2)$ there is a positive direct influence of job satisfaction on $O C B,(3)$ there is a positive direct influence between leader member exchange with job satisfaction. The implication of this research is an attempt to improve teachers' OCB can be done by improving leader member exchange and job satisfaction.
\end{abstract}

Keywords: organizational citizenship behavior, leader member exchange, job satisfaction

\section{PENDAHULUAN}

Diantara beberapa sumber daya yang ada di organisasi, sumber daya manusia (karyawan) merupakan sumber daya yang paling penting. Hal ini dikarenakan manusia memiliki talenta, kemampuan, skill, dan motivasi yang akan menuntun pada berbagai macam perilaku dan hasil kerja sehingga organisasi yang baik dan berkembang akan menitikberatkan pada perubahan internal yang positif berupa sumber daya manusia yang berkualitas dalam menampilkan kinerja sebagai upaya untuk menghadapi perubahan-perubahan lingkungan dan tuntutan global.

Dalam Jurnal Psikologi Industri dan Organisasi Volume 1 No. 02, Juni 2012 dijelaskan di era globalisasi ini, menuntut organisasi tidak hanya memiliki sumber daya manusia yang berkualitas, tetapi juga sumber daya manusia yang mau menjalankan tanggung jawab di luar tugas yang dipersyaratkan padanya, dan menampilkan perilakuperilaku menolong rekan kerja yang mengalami kesulitan untuk meningkatkan efektivitas organisasi. Sejalan dengan tantangan kehidupan global, peran dan tanggung jawab guru pada masa mendatang akan semakin kompleks, sehingga menuntut guru untuk senantiasa melakukan berbagai peningkatan dan penyesuaian kemampuan profesionalnya. Guru harus lebih dinamis dan kreatif dalam mengembangkan proses pembelajaran peserta didik serta memiliki komitmen untuk senantiasa mengembangkan potensi peserta didiknya dalam rangka mensukseskan tujuan pendidikan nasional yang tertera pada pasal 3 Undang-Undang No. 20 Tahun 2003 tentang Sistem Pendidikan Nasional.

Sejalan dengan tantangan kehidupan global, peran dan tanggung jawab guru pada masa mendatang akan semakin kompleks, sehingga menuntut guru untuk senantiasa

\footnotetext{
${ }^{1}$ Karyawan Swasta di Jakarta
} 
melakukan berbagai peningkatan dan penyesuaian kemampuan profesionalnya. Guru harus lebih dinamis dan kreatif dalam mengembangkan proses pembelajaran peserta didik serta memiliki komitmen untuk senantiasa mengembangkan potensi peserta didiknya dalam rangka mensukseskan tujuan pendidikan. OCB merupakan perilaku positif para individu yang terdapat di dalam organisasi, yang terekspresikan dalam bentuk kesediaan secara sadar dan sukarela untuk bekerja. Munculnya OCB memberikan dampak positif tidak hanya bagi individu itu sendiri tetapi juga memberikan kontribusi pada organisasi lebih daripada apa yang dituntut secara formal oleh organisasi tersebut. Organisasi yang baik dan berhasil memiliki anggota yang melampaui tanggung jawab pada pekerjaan formal dan bebas memberikan waktu, tenaga dan pikiran mereka untuk berhasil dalam pekerjaan yang ditugaskan. Perilaku tersebut tidak ditentukan, namun memberikan kontribusi terhadap kelancaran fungsi organisasi. Organisasi tidak bisa bertahan atau berkembang tanpa anggotanya berperilaku sebagai warga yang baik dan terlibat dalam segala macam perilaku positif.

\section{Organizational Citizenship Behavior (OCB)}

Menurut Jenifer M. George dan Gareth R. Jones (2012:87), “organizational citizenship behavior (OCBs) is behavior that is above and beyond the call of duty-that is, behavior that is not required of organizational members but nonetheless necessary for organizational survival and effectiviness". Definisi ini mengandung makna bahwa OCB itu merupakan perilaku yang melebihi panggilan tugas dimana merupakan perilaku yang tidak ditentukan oleh anggota organisasi, tetapi meskipun demikian penting bagi kelangsungan hidup dan efektifitas organisasi. Jhon R. Schermerhorn (2010:336) menyatakan bahwa, "organization citizenship behavior is a willingness to go beyond the call of duty or go to the extra mile in one's work". Organization citizenship adalah kemauan untuk menjalankan pekerjaan di luar kewajibannya. Seseorang yang memiliki organization citizenship yang tinggi akan melakukan segala sesuatu untuk organisasinya walaupun tidak dibutuhkan untuk membantu kinerja organisasi.

Penjelasan Organ dalam Fred Luthans (2011:149) Organizational Citizenship Behavior (OCB) adalah "individual behavior that is discretionary, not directly or explicity recognized by the formal reward system, and that in the aggregate promotes the effective functioning of the organization. Organ mendefinisikan OCB sebagai perilaku individu yang memiliki kebebasan untuk memilih, tidak langsung atau eksplisit diakui oleh sistem penghargaan formal, dan secara keseluruhan mendorong efektifitas fungsi organisasi.

Sementara Colquitt, LePine dan Wesson (2015:39) mendefinisikan, "citizenship behavior is defined as voluntary employee activites that may or may not be rewardes but contribute to the organizational by improving the overall quality of setting in which work take place". Perilaku citizenship adalah kegiatan pegawai yang dapat atau tidak dapat penilaian tetapi memberikan kontribusi untuk organisasi dengan memberikan kualitas terbaik dalam bekerja. Rea Andre (2008:126) memberikan difinisi hampir sama, "behavior on be helf of the organizational that go beyond normal job ekspectation, and which may even serve a larger societal purpose". Organization citizenship adalah perilaku yang menjadi bagian dari organisasi sebagai bentuk pekerjaan di luar ekspektasi normal dan dapat memberikan pelayanan lebih untuk mencapai tujuan organisasi.

Hal senada dikemukakan oleh Robbins and Mary Coulter (2013:373) bahwa," organizational citizenship behavior (OCB) is discretionaly behavior that's no part of an employee's formal job requirements, but which promotes the effeective functioning of the organization". Berdasarkan definisi di atas, OCB adalah perilaku sukarela yang tidak 
menjadi bagian dari persyaratan kerja formal seorang pegawai, namun meningkatkan efektifitas fungsi organisasi.

Berdasarkan uraian di atas, dapat disintesiskan bahwa organizational citizenship behavior $(O C B)$ adalah perilaku sukarela pegawai, yang mengutamakan kepentingan organisasi dan dapat meningkatkan efisiensi dan efektifitas fungsi organisasi dengan lima indikator, yaitu: (1) membantu rekan kerja, (2) menghormati rekan kerja, (3) sikap sportif, (4) tindakan taat peraturan, dan (5) tindakan berpartisipasi.

\section{Leader Member Exchange (LMX)}

Jennifer M. George dan Gareth R. Jones, menjelaskan LMX sebagai berikut: Leader-member exchange a theory that describes the different kinds of relationship that may develop between a leader and a follower and what a leader and the follower give to and received back from the relationship. Pertukaran pemimpin - anggota, merupakan sebuah teori yang menggambarkan jenis hubungan antara pemimpin dan pengikut yang saling memberi dan saling menerima.

Achua dan Lussier mendefinisikan, "leader-member exchange (LMX) is define as the quality of the exchange relationship between a leader and follower" Pertukaran antara pemimpin - anggota didefinisikan sebagai kualitas hubungan pertukaran antara pemimpin dan pengikut.

Yukl dalam uraiannya tentang LMX mengatakan bahwa, "(LMX) that describes how a leader develops an exchange relationship over time with each subordinate as the two parties influence each other and negotiate the subordinate's role in the organization". (LMX) menggambarkan bagaimana seorang pemimpin mengembangkan sebuah hubungan pertukaran dengan masing-masing bawahan melewati batas waktu di mana kedua pihak saling mempengaruhi satu sama lain dalam peran mereka pada organisasi. Selanjutnya Yukl juga mengatakan bahwa, "leader - member exchange (LMX) theory describes the role-making processes between a leader and each individual subordinate and the exchange relationship that develops over time". Teori pertukaran pemimpin - anggota yang menjelaskan tentang pembuatan peran di antara satu pemimpin dan masing-masing bawahan yang melampaui batas waktu.

Achua dan Lussier mengatakan bahwa: The relationship transition from an economic-based exchange, which is contractual in nature to a social exchange characterized by mutual trust, loyalty, and respect between the leader and the follower. Hubungan pertukaran antara pimpinan dan anggota yang alami dari sudut pandang ekonomi ditandai dengan rasa saling percaya, loyal satu terhadap yang lain, dan saling menghormati.

Dari rangkaian penjelasan tersebut, dapat disintesiskan bahwa LMX adalah hubungan dua arah antara pemimpin dan anggota yang bertujuan untuk meningkatkan kesuksesan organisasi dengan indikator: (1) saling menghormati kemampuan satu sama lain, (2) saling percaya, dan (3) saling memenuhi kewajiban.

\section{Kepuasan Kerja}

Schermerhorn et al (2010:72) mendefinisikan kepuasan kerja lebih pada sejauh mana seorang individu merasa positif atau negatif tentang pekerjaan, sebagaimana dalam pernyataannya, "job satisfaction is the degree to which an individual feels positive or negative about a job". Pendapat yang tidak jauh berbeda dikemukakan oleh Locke dalam Anderson et al (2001:25), "job satisfaction is a pleasurable or positive emotional state resulting from the appraisal of one's job or job experiences".Kepuasan kerja merupakan konsep yang rumit dan beragam, yang dapat berarti hal yang berbeda untuk orang yang berbeda. Kepuasan kerja biasanya terkait dengan motivasi. Sebagaimana dikemukakan Mullins (2005:700) "job satisfaction is a complex and multifaceted concept, which can mean different 
things to different people. Job satisfaction is usually linked with motivation, but the nature of this relationship is not clear. Satisfaction is not the same as motivation". Kepuasan kerja mengacu pada sikap individu secara umum terhadap pekerjaannya. Seseorang dengan tingkat kepuasan kerja yang tinggi mempunyai sikap positif terhadap pekerjaannya, sebaliknya, seseorang tidak puas mempunyai sikap negatif terhadap pekerjannnya. Kepuasan kerja pada hakikatnya merupakan penilaian seseorang terhadap pekerjaan yang dirasakannya.

Kepuasan kerja merupakan kumpulan perasaan dan keyakinan bahwa orang miliki tentang pekerjaan mereka saat ini. Selain pekerjaan mereka secara keseluruhan, karyawan juga dapat memiliki sikap tentang berbagai aspek pekerjaan mereka seperti jenis pekerjaan yang mereka lakukan, rekan kerja mereka, supervisor, atau bawahan, dan gaji mereka hal tersebut sebagaimana dikatakan George dan Jones (2012:71) "job satisfaction is the collection of feelings and beliefs that people have about their current jobs. People's levels or degrees of job satisfaction can range from extreme satisfaction to extreme dissatisfaction. Recall from the opening case how job satisfaction levels are very high at Nugget Markets. In addition to having attitudes about their jobs as a whole, people also can have attitudes about various aspects of their jobs such as the kind of work they do, their coworkers, supervisors, or subordinates, and their pay". Seseorang yang mempunyai kepuasan kerja yang tinggi akan melakukan tindakan positif terhadap pekerjaannya, sebaliknya orang yang tidak puas akan menunjukan tindakan yang negatif. Konsekuensinya adalah orang yang puas akan bersifat positif, misalnya rajin bekerja, sungguh-sungguh, dan mempunyai semangat kerja, sementara yang tidak puas akan berperilaku negatif, misalnya jarang masuk kerja, melalaikan tugas dan malas. Kepuasan kerja adalah ungkapan perasaan seseorang tentang kesejahteraan untuk melakukan pekerjaan, bahwa kepuasan kerja adalah sikap seseorang terhadap pekerjaan mereka. Sikap itu berasal dari persepsi mereka tentang pekerjaan, persepsi adalah proses kognitif (pemberian arti) yang digunakan oleh seseorang untuk menafsirkan dan memahami cara pandang individu dalam melihat hal yang sama dengan cara yang berbeda-beda.

Berdasarkan penjelasan di atas, maka dapat disintesiskan bahwa kepuasan kerja adalah perasaan senang dan tidak senang individu berkaitan dengan pekerjaannya, dengan indikator (1) perasaan terhadap kondisi organisasi, (2) perasaan terhadap pekerjaan itu sendiri, (3) perasaan terhadap upah/gaji, (4) perasaan terhadap kesempatan promosi, (5) perasaan terhadap pengawasan dan (6) perasaan terhadap rekan kerja. 


\section{METODE}

Penelitian ini bertujuan untuk menguji pengaruh langsung; (1) LMX terhadap OCB, (2) kepuasan kerja terhadap OCB, dan (3) LMX terhadap kepuasan kerja. Penelitian menggunakan metode survey dengan pendekatan teknik analisis jalur. Penelitian dilaksanakan di SD Swasta di Kecamatan Menteng, Jakarta Pusat. Populasi terjangkau penelitian ini sejumlah 101 guru. Sampel penelitian sebanyak 81 orang. Analisa data untuk pengujian hipotesis akan dilakukan dengan menggunakan teknik analisis jalur, yaitu teknik yang diterapkan untuk menjelaskan pengaruh antara variabel-variabel penelitian. Sebelum dilaksanakan analisis jalur, uji signifikan regresi dan uji linearitas regresi sebagai prasyarat uji statistik dilakukan pengujian penormalan data dari masing-masing variabel penelitian dengan Uji-Liliefors, Statistik inferensial digunakan untuk menguji hipotesis tentang pengaruh antar variabel dengan menggunakan tehnik analisis jalur.

\section{HASIL DAN PEMBAHASAN}

\section{Pengaruh LMX terhadap OCB}

Dari hasil pengujian hipotesis pertama dapat disimpulkan bahwa terdapat pengaruh langsung positif LMX terhadap OCB dengan nilai koefisien korelasi sebesar 0,532 dan nilai koefisien jalur sebesar 0,387. Ini memberikan makna LMX berpengaruh langsung terhadap OCB. Jenifer M. George dan Gareth R. Jones (2012:87) menjelaskan, "organizational citizenship behavior (OCBs) is behavior that is above and beyond the call of duty-that is, behavior that is not required of organizational members but nonetheless necessary for organizational survival and effectiviness". Definisi ini mengandung makna bahwa OCB itu merupakan perilaku yang melebihi panggilan tugas dimana merupakan perilaku yang tidak ditentukan oleh anggota organisasi, tetapi meskipun demikian penting bagi kelangsungan hidup dan efektifitas organisasi. Sedangkan Jhon R. Schermerhorn (2010:336) menyatakan bahwa, "organization citizenship behavior is a willingness to go beyond the call of duty or go to the extra mile in one's work". Organization citizenship adalah kemauan untuk menjalankan pekerjaan di luar kewajibannya. Seseorang yang memiliki organization citizenship yang tinggi akan melakukan segala sesuatu untuk organisasinya walaupun tidak dibutuhkan untuk membantu kinerja organisasi.

Hasil penelitian ini senada dengan pendapat beberapa ahli di antaranya adalah Podsakoff: We believe that our finding that LMX predicts citizenship behaviors moderately strongly has important implications for calibrating the predictive efficacy of LMX theory. That is, to the extent that the positive outcomes of employees' citizenship behaviors and of their task performance are not completely overlapping, the fact that LMX predicts citizenship behaviors as strongly as it predicts task performance suggests that the benefits associated with high-quality leader-member exchanges exceed what has been suggests by the validity of LMX in predicting task performance alone.

LMX merupakan teori tentang kepemimpinan yang berhubungan dengan peningkatan antara pimpinan dan bawahan dalam pencapaian tujuan organisasi sebagai tujuan utama dasar pemikiran teori LMX bahwa dalam sebuah organisasi, pemimpin mengembangkan tipe hubungan yang berbeda dengan bawahannya dan pemimpin menetapkan bahwa adanya hubungan khusus dengan suatu grup yang terdiri dari beberapa pengikutnya. Group ini dibagi menjadi dua, yaitu in-group dan out-group. Pada in-group, bawahan lebih dipercaya, mendapatkan perhatian dalam porsi yang lebih 
besar dari atasan, dan mendapatkan hak-hak khusus. Bawahan dalam kelompok outgroup hanya mendapatkan sedikit waktu yang diberikan oleh leader, sedikit kontrol yang diberikan oleh leader,dan hubungan leader dengan out-group. Kesimpulannya bahwa LMX adalah kualitas hubungan timbal balik antara atasan dan bawahan dimana atasan memiliki kualitas hubungan timbal balik yang berbeda dengan masing-masing bawahannya, ditinjau berdasarkan pengenalan terhadap potensi dan posisi bawahannya adanya rasa dan keinginan untuk saling mendukung adanya pimpinan yang memahami terhadap permasalahan dan kebutuhan kerja dan efektifitas hubungan kerja yang efektif maka akan terjadi feed-back atau hutang budi dari bawahannya dengan adanya perilaku extra role atau OCB dari bawahan dan LMX merupakan salah satu prediktor dari OCB.

\section{Pengaruh Kepuasan Kerja terhadap OCB}

Dari hasil pengujian hipotesis kedua dapat disimpukan bahwa terdapat pengaruh langsung positif kepuasan kerja terhadap OCB dengan nilai koefisien korelasi sebesar 0,532 dan nilai koefisien jalur sebesar 0,383. Ini memberikan makna kepuasan kerja berpengaruh langsung terhadap OCB. Mullins (2005:700) menjelaskan “job satisfaction is a complex and multifaceted concept, which can mean different things to different people. Job satisfaction is usually linked with motivation, but the nature of this relationship is not clear. Satisfaction is not the same as motivation". Kepuasan kerja mengacu pada sikap individu secara umum terhadap pekerjaannya. Seseorang dengan tingkat kepuasan kerja yang tinggi mempunyai sikap positif terhadap pekerjaannya, sebaliknya, seseorang tidak puas mempunyai sikap negatif terhadap pekerjannnya. Kepuasan kerja pada hakikatnya merupakan penilaian seseorang terhadap pekerjaan yang dirasakannya. Kepuasan kerja merupakan kumpulan perasaan dan keyakinan bahwa orang miliki tentang pekerjaan mereka saat ini. Selain pekerjaan mereka secara keseluruhan, karyawan juga dapat memiliki sikap tentang berbagai aspek pekerjaan mereka seperti jenis pekerjaan yang mereka lakukan, rekan kerja mereka, supervisor, atau bawahan, dan gaji mereka. Sedangkan George dan Jones (2012:71) menjelaskan "job satisfaction is the collection of feelings and beliefs that people have about their current jobs. People's levels or degrees of job satisfaction can range from extreme satisfaction to extreme dissatisfaction. Recall from the opening case how job satisfaction levels are very high at Nugget Markets. In addition to having attitudes about their jobs as a whole, people also can have attitudes about various aspects of their jobs such as the kind of work they do, their coworkers, supervisors, or subordinates, and their pay". Seseorang yang mempunyai kepuasan kerja yang tinggi akan melakukan tindakan positif terhadap pekerjaannya, sebaliknya orang yang tidak puas akan menunjukan tindakan yang negatif. Konsekuensinya adalah orang yang puas akan bersifat positif, misalnya rajin bekerja, sungguh-sungguh, dan mempunyai semangat kerja, sementara yang tidak puas akan berperilaku negatif, misalnya jarang masuk kerja, melalaikan tugas dan malas.

Hasil penelitian ini senada dengan pendapat beberapa ahli di antaranya adalah Colquitt, Le Pine dan Wesson sebagai berikut, "satisfied employees engage in more frequent "extra mile" behaviours to help their coworkers and their organization" Karyawan yang puas terlibat dalam perilaku jauh lebih baik yang lebih sering untuk menolong rekan kerja dan organisasi mereka.

Menurut Fred Luthans, pengaruh kepuasan kerja terhadap OCB dalam bagian salah satu prinsip organisasi dalam bukunya, yakni, "other additional variables discussed in this chapter such as job satisfaction and organizational commitment predict and may lead to 
$O C B$ 's" Variabel tambahan lainnya yang di bahas di bab ini seperti kepuasan kerja dan komitmen organisasi menentukan dan memastikan perilaku OCB.

Perilaku OCB, walaupun secara kuantitas tidak berpengaruh pada proyeksi imbalan yang diterima karyawan karena memang tidak tercantum dalam prosedur distribusi imbalan yang diterima karyawan, sangat berpengaruh pada kinerja, komitmen dan perilaku karyawan diluar organisasi atau diluar kondisi kerjanya seperti menjaga nama baik organisasi, memperbaiki citra organisasi dan menjalin hubungan baik dengan masyarakat sekitar organisasi sebagai hasil perlakukan yang diterima karyawan bahwa mereka diperlakukan dengan baik dan adil oleh organisasi yang menimbulkan kepuasan tersendiri bagi karyawan.

Senada dengan pendapat Robbins dan Judge yang menyatakan, " $t$ seems logical to assume job satisfaction should be a major determinant of an employee's organizational citizenship behavior (OCB). Satisfied employee would seem more likely to talk positively about the organization, help others and go beyond the normal expectations in their job".

Patut dikatakan masuk akal untuk menganggap bahwa kepuasan kerja bisa menjadi faktor utama yang menentukan OCB seorang karyawan. Karyawan yang puas akan terlihat berbicara yang bagus tentang organisasinya, menolong orang lain dan berperilaku jauh lebih baik di atas harapan kerja mereka. Mereka anggap ini adalah 'panggilan' tugas karena mereka ingin balas jasa mengenai pengalaman positif mereka atas perlakuan organisasi. Balas jasa mengenai kepuasan yang dialami karyawan tentulah atas anggapan keadilan, dimana jika mereka menolong rekan mereka dan berperilaku lebih baik dari yang diharapkan itu karena rekan sesama mereka mendukung mereka juga. Begitu pula jika karyawan tidak merasakan atasan mereka, prosedur organisasi, atau kebijakan upah terasa adil, kepuasan kerja mereka terlihat menurun drastis dan tentu saja hal ini akan berakibat mereka berperilaku negatif.

Manfaat luar biasa yang didapat dari perilaku OCB baik itu untuk individu karyawan, tim kerja, organisasi maupun masyarakat sekitar memicu pihak manajemen mengembangkan dan memelihara perilaku OCB. OCB merupakan bentuk lain dari kinerja oleh karena itu OCB harus diorganisasikan .

Berikut pendapat dari Steve M. Jex: If employees perform OCB primarily because they are satisfied with their jobs, or feel that they have been treated fairly, organizations can influence the performance of OCB by treating employee fairly and taking steps to enhance satisfaction.

Jika karyawan berperilaku OCB semata-mata karena mereka puas dengan pekerjaan mereka, atau merasakan bahwa mereka diperlakukan dengan adil, organisasi dapat mempengaruhi hasil OCB dengan memperlakukan karyawan dengan adil dan membuat langkah-langkah untuk meningkatkan kepuasan karyawan.

Hal tersebut di atas senada dengan pendapat Gibson dkk., yang menyatakan, "although job satisfaction doesn't influence quantity and quality of performance, it does influence citizenship behavior." Meskipun kepuasan kerja tidak mempengaruhi kuantitas dan kualitas kinerja, kepuasan kerja mempengaruhi OCB. Tentu saja OCB merupakan hal yang tidak bisa ditampik lagi dimana pada selanjutnya OCB akan mempengaruhi kinerja organisasi dengan mendukung kegiatan kerja secara terus-menerus dan mempengaruhi penilaian kinerja. Para karyawan yang berperilaku OCB seperti menolong orang lain atau memberikan ide-ide membangun menerima penilaian kinerja yang jauh lebih baik. Dengan pengaruh inilah, para manajer berusaha terus mencari cara dan program yang dapat meningkatkan kepuasan kerja.

\section{Pengaruh LMX terhadap Kepuasan Kerja}

Dari hasil pengujian hipotesis ketiga dapat disimpulkan bahwa terdapat 
pengaruh langsung positif LMX terhadap kepuasan kerja dengan nilai koefisien korelasi sebesar 0,378 dan nilai koefisien jalur sebesar 0,378. Ini memberikan makna LMX berpengaruh langsung terhadap kepuasan kerja. Jennifer M. George dan Gareth R. Jones, menjelaskan LMX sebagai berikut: Leader - member exchange a theory that describes the different kinds of relationship that may develop between a leader and a follower and what a leader and the follower give to and received back from the relationship. Pertukaran pemimpin - anggota, merupakan sebuah teori yang menggambarkan jenis hubungan antara pemimpin dan pengikut yang saling memberi dan saling menerima. Achua dan Lussier mendefinisikan, "leader - member exchange (LMX) is define as the quality of the exchange relationship between a leader and follower" Pertukaran antara pemimpin - anggota didefinisikan sebagai kualitas hubungan pertukaran antara pemimpin dan pengikut. Yukl dalam uraiannya tentang LMX mengatakan bahwa, "(LMX) that describes how a leader develops an exchange relationship over time with each subordinate as the two parties influence each other and negotiate the subordinate's role in the organization". (LMX) menggambarkan bagaimana seorang pemimpin mengembangkan sebuah hubungan pertukaran dengan masing-masing bawahan melewati batas waktu di mana kedua pihak saling mempengaruhi satu sama lain dalam peran mereka pada organisasi.

Hasil penelitian ini senada dengan pendapat beberapa ahli di antaranya adalah Greenberg menjelaskan, "Leader Member Exchange (LMX) suggesting that leaders from different relation with various subordinates and that the nature of such dyadic exchanges can exert strong effects on subordinates performance and satisfaction" LMX menunjukkan bahwa pemimpin yang mempunyai hubungan yang berbeda dengan berbagai bawahan dapat memberikan pengaruh yang kuat pada kinerja dan kepuasan pegawai (bawahan).

Steve M. Jex berpendapat: Theory is expansion of its scope. For most people, the unique relationship they develop with their immediate supervisor is one of the most important dimensions of their work experience. As such, it may influence many work outcomes. For example, found that a high-quality LMX moderated the relationship between role ambiguity and job satisfaction.

Tantangan lain pada teori LMX adalah perluasan ruang lingkup. Bagi kebanyakan orang, hubungan unik yang mereka kembangkan dengan atasan adalah salah satu dimensi yang paling penting dari pengalaman kerja mereka. Dengan demikian, hal itu mungkin mempengaruhi banyak hasil kerja. Sebagai contoh, kualitas LMX yang tinggi menjadi moderator hubungan antara peran ambiguitas dan kepuasan kerja.

Selanjutnya Vecchio mengemukakan bahwa, "in group members, in many respects enjoy the benefit of enriches job opportunities. Further, it is expected that in group members will display greater job satisfaction" Anggota kelompok dalam, akan menikmati keuntungankeuntungan pekerjaan dalam banyak kesempatan. Anggota kelompok yang menikmati keuntungan pekerjaan tersebut akan menunjukkan kepuasan kerja lebih besar.

Miner mengemukakan bahwa, "LMX was almost as good and a better prediction of satisfaction measures" LMX merupakan prediktor yang baik untuk mengukur kepuasan.

\section{PENUTUP}

Kesimpulan: Berdasarkan hasil pengujian hipotesis dan pembahasan yang telah dikemukakan diperoleh kesimpulan penelitian sebagai berikut: (1) LMX berpengaruh langsung positif terhadap OCB. Artinya, LMX yang kuat mengakibatkan peningkatan OCB guru SD Swasta di Kecamatan Menteng, Jakarta Pusat. (2) kepuasan kerja berpengaruh langsung positif terhadap OCB. Artinya, peningkatan kepuasan kerja mengakibatkan peningkatan OCB guru guru SD Swasta di Kecamatan Menteng, Jakarta Pusat. (3) LMX berpengaruh langsung terhadap kepuasan kerja. Artinya, peningkatan 
LMX mengakibatkan peningkatan kepuasan kerja guru guru SD Swasta di Kecamatan Menteng, Jakarta Pusat.

Saran: Berdasarkan kesimpulan penelitian dapat dirumuskan beberapa saran (1) Bagi Yayasan Pendidikan SD Swasta di Kecamatan Menteng,Jakarta Pusat hendaknya memfasilitasi kepala sekolah dan para guru untuk melakukan pengembangan keprofesian guru dengan mengadakan berbagai rupa kegiatan pendidikandan pelatihan, seminar, workshop serta kegiatan kebersamaan lainnya sehingga kepala sekolah dan paraguru selalu dapat berkembang dan belajar serta mendapatkan pengetahuan dan keterampilan yang bermanfaat bagi pengembangan karirnya. (2) Bagi kepala sekolah sebagai atasan langsung guru di sekolah hendaknya berperan aktif mengupayakan peningkatan OCB guru dalam bekerja. Kepala sekolah SD Swasta di Kecamatan Menteng, Jakarta Pusat diharapkan mampu mengembangkan dan menganalisa faktor-faktor yang dapat meningkatkan LMX dan kepuasan kerja guru. Kemudian melakukan peran aktifsebagai realisasi dalam mewujudkan dukungan kepala sekolah terhadap guru dalam upaya peningkatan LMX dan kepuasan kerja guru. (3) Bagi guru-guru SD Swasta di Kecamatan Menteng, Jakarta Pusat hendaknya dapat berperan secara aktif dalam membangun hubungan dua arah dengan kepala sekolah. Dengan LMX yang berkualitas akan mewujudkan dimensi kepuasan kerja. Dengan demikian LMX yang berkualitas dan kepuasan kerja yang tinggi akan berdampak pada peningkatan OCB.

\section{DAFTAR RUJUKAN}

Andre, Rea. Organization Behavior: An Introduction to Your Live in Organizational. United States Person International Edition, 2008.

Colquitt, Jason A.,Jeffery A. LePine, dan Michael J. Wesson. Organizational Behavior: Improving Performance and Commitment in the Workplace, Fourth Edition. New York: McGraw-Hill Education, 2015

George, Jennifer M. dan Gareth R. Jones, Organizational Behavior, Understanding and Managing, Sixth Edition. New Jersey: Pearson Education Prentice Hall, 2012

Luthans, Fred,Organization Behavior: An Evidence-Based Approach, Twelfth Edition. New York: McGraw-Hill, 2011

Robbins, Stephen P. dan Mary Coulter. Management, Seven Edition. Australia: Pearson Education, 2013

F. Achua D. B. A, Christopher dan Robert N. Lussier, Effective Leadership, Fifth International Edition. Canada: South-Western Cengage Learning, 2013.

Yukl, Gary. Leadership in Organization, Seventh Edition. New Jersey: Pearson Education, Inc.,2010.

Mullins, Laurie J. Management and Organizational Behavior Ninth edition. New Jersey: Prentice Hall, 2010. 
Schermerhorn, John R., et al. Organizational Behavior. Hoboken: John Wiley \& Son Inc, 2010. 